\title{
Tingkat Pengetahuan Pasien dalam Melakukan Cara Mengontrol dengan Perilaku Pasien Halusinasi Pendengaran
}

\author{
Marisca Agustina \\ Program Studi Ilmu Keperawatan \\ Sekolah Tinggi Ilmu Kesehatan Indonesia Maju \\ Jln. Harapan no.50, Lenteng Agung Jakarta Selatan 12610 \\ Telp: (021) 78894045. Email : marisca_duff@yahoo.com
}

\begin{abstract}
Abstrak
Halusinasi merupakan gangguan dari luar yang dapat terjadi pada sistem pengindraan dimana terjadi dan penyerapan atau persepsi panca indra terjadi pada saat kesadaran individu itu penuh dan baik..Penelitian ini bertujuan untuk mengidentifikasi hubungan antara tingkat pengetahuan pasien dalam melakukan cara mengontrol dengan perilaku pasien halusinasi pendengaran di Rs. Jiwa Dr. Soeharto Heerdjan Jakarta. Desain yang digunakan dalam penelitian ini adalah destriktif korelasi dengan pendekatan cross sectional. Teknik pengambilan sampel adalah dengan metode total sampling yaitu sebanyak 50 orang.Instrumen pengumpulan data adalah lembar kuesioner. Dan teknik analisa data dengan menggunakan chi-square. Hasil penelitian menunjukkan ada hubungan pengetahuan pasien dengan perilaku pasien halusinasi pendengaran dengan nilai $\mathrm{p}$ value $=0,001(\mathrm{p}=>0,05)$. untuk itu diharapkan kepada pasien agar meningkatkan tingkat pengetahuan pasien dalam melakukan cara mengontrol sehingga perilaku pasien halusinasi pendengaran destruktif dalam perilakunya.
\end{abstract}

Kata kunci : Pengetahuan, Halusinasi Pendengaran.

\begin{abstract}
Hallucinations are outside interference can occur in sensory systems where absorption occurs and or sensory perception occurs when an individual's consciousness is full and good. This study aims to identify the relationship between the level of knowledge of the patient in doing controlling the behavior of patients with auditory hallucinations in Rs. Dr soul. Suharto Heerdjan Jakarta. Design used in this study is destriktif with cross sectional correlation. The sampling technique is a method of sampling that total as many as 50 people. Data collection instrument was a questionnaire. And techniques of data analysis using the chi-square. The results showed no correlation with the patients' knowledge of the behavior of patients with auditory hallucinations $p$ value $=0.001(p=\langle 0.05)$. for it is expected to increase the level of knowledge of the patient so that the patient in doing so as a way to control the destructive behavior of auditory hallucinations in patients behavior.
\end{abstract}

Keywords $\quad$ : Knowledge, Auditory Hallucinations. 


\section{Pendahuluan}

Persepsi didefinisikan sebagai suatu proses diterimanya rangsangan sampai didasari dan dimengerti oleh pengindraan atau sensasi: proses penerimaan rangsang. ${ }^{1}$ Persepsi merupakan tanggapan indra terhadap rangsangan yang datang dari luar dimana rangsangan tersebut dapat berupa rangsangan penglihatan, penciuman, pendengaran, pengecapan, dan perabaan interpretasi (tafsir) terhadap rangsangan yang datang dari luar itu mengalami gangguan sehingga terjadilah salah tafsir (misinterpretation). Salah tafsir tersebut terjadi antara lain karena adanya keadaan afek yang luar biasa seperti marah, takut, excited (tercengang), sedih dan nafsu memuncak sehingga terjadi gangguan atau perubahan persepsi. ${ }^{1}$

Perubahan persepsi adalah ketidak mampuan manusia dalam membedakan rangsang yang timbul dari sumber internal seperti pikiran, persaan, sensasi somatik dengan impuls dan stimulus eksternal. Dengan maksud bahwa manusia masih mempunyai kemampuan dalam membandingkan dan mengenal mana yang merupakan respon dari luar dirinya. Manusia yang mempunyai ego yang sehat dapat membedakan antara fantasi dan kenyataan. Mereka dalam menggunakan proses pikir yang logis membedakan dengan pengalaman dan dapat menvalidasikan serta mengevaluasinya secara akurat. ${ }^{1}$

Adapun peran perawat dalam memberikan asuhan keperawatan jiwa diantaranya, preventif, promotif, kuratif, rehabilitatif. Upaya preventif yaitu dengan mencegah perilaku yang dapat merusak diri sendiri dan orang lain. Upaya promotif yaitu memberikan pendidikan kesehatan bagi keluarga tentang merawat klien gangguan sensori persepsi halusinasi. Upaya kuratif yaitu kolaborasi dengan tim kesehatin untuk memberikan pengobatan, dan upaya rehabilitatif yaitu membantu klien dalam kegiatan sehari-hari dan dapt kembali menjadi kehidupan normal. ${ }^{2}$
Peran perawat pada klien meliputi aspek promotif, preventif, kuratif dan rehabilitatif. Promotif adalah memberikan penjelasan tentang gangguan jiwa gangguan sensori persepsi: halusinasi pendengaran pada masyarakat umum,mulai dari pengertian, penyebab, tanda dan gejala sampai dengan komplikasi yang akan terjadi bila tidak segera ditangani. Preventif adalah memberi penjelasan cara pencegahan pasien dengan gangguan jiwa terutama dengan pasien gangguan sensori persepsi: halusinasi pendengaran. Kuratif ada lahperan perawat memberikan asuhan keperawatan pada pasien gangguan jiwa terutama dengan gangguan sensori persepsi:halusinasi pendengaran secara mandiri serta memberikan obat-obatan sebagai tindakan kolaborasi dengan dokter. ${ }^{3}$

Rehabilitatif peran perawat dalam memperkenalkan pada anggota keluarga cara merawat pasien dengan gangguan jiwa terutama dengangangguan sensori persepsi: halusinasi pendengaran di rumah. ${ }^{2}$

Halusinasi adalah persepsi sensorik yang keliru dan melibatkan panca indra (Isaacs, 2002). Halusinasi adalah gangguan dari luar yang dapat terjadi pada sistem pengindraan dimana terjadi. Halusinasi adalah penyerapan atau persepsi panca indra tanpa adanya rangsangan dari luar yang dapat terjadi pada sistem pengindraan dimana terjadi pada saat kesadaran individu itu penuh dan baik. Maksudnya rangsangan tersebut terjadi pada saat dapat menerima rangsangan dari luar dan dari dalam diri individu. Dengan kata lain klien berespon terhadap rangsangan yang tidak nyata, yang hanya dirasakan oleh klien dan tidak dapat dibuktikan. ${ }^{4}$

Halusinasi pendengaran adalah mendengar suara manusia, hewan atau mesin, barang, kejadian alamiah dan musik dalam keadaan sadar tanpa adanya rangsang apapun. Halusinasi pendengaran adalah mendengar suara atau bunyi yang berkisar dari suara sederhana sampai suara yang berbicara mengenai klien sehingga klien berespon terhadap suara atau bunyi tersebut. ${ }^{5}$

Permasalahan hidup yang semakin berat dialami hampir oleh semua kalangan masyarakat mulai dari masalah rumah tangga, stress di tempat kerja, tingginya tingkat pengangguran, sampai sulitnya mencari makan, situasi tersebut dapat mengakibatkan 
gangguan jiwa seperti, depresi bahkan sampai sampai kasus-kasus bunuh diri. Jumlah kematian itu belum termasuk dengan kematian akibat obat terlarang yang mencapai 50 ribu tiap tahunnya. Pada study terbaru WHO di 14 negara menunjukkan bahwa pada negaranegara berkembang sekitar $76-85 \%$ kasus gangguan jiwa paruh tidak dapat pengobatan apapun pada tahun utama. Krisis ekonomi dunia yang semakin berat mendorong jumlah penderita gangguan jiwa di dunia, dan Indonesia khususnya kian meningkat, diperkirakan sekitar 50 juta atau $25 \%$ dari juta penduduk Indonesia mengalami gangguan jiwa. ${ }^{6}$

WHO menunjukkan bahwa diperkirakan sebanyak 873.000 orang melakukan bunuh diri tiap tahun di dunia. Oleh karena itu perlu diketahui apa saja yang dibutuhkan dalam rangka membangun kesadaran dan mengurangi risiko kejadian bunuh diri. Begitu juga kasus bunuh diri di Amerika mencapai 30.000 orang pertahun. Angka ini menunjukkan jumlah orang yang mencoba bunuh diri jauh lebih besar lagi, diperkirakan 8-10 kali lebih besar dari jumlah tersebut. ${ }^{6}$

Penyebab bunuh diri pada individu gangguan jiwa karena stress yang tinggi dan kegagalan mekanisme koping yang digunakan dalam mengatasi masalah. Oleh karena itu, WHO meminta perhatian para praktisi kesehatan dan pihak terkait lainnya untuk memandang bunuh diri sebagai penyebab utama kematian dini yang dapat dicegah. Seseuai denga tema kesehatan jiwa se-dunia : Membangun Kesadaran Mengurangi Risiko: Gangguan Jiwa dan Bunuh Diri. ${ }^{7}$

pada tahun 1882 pelayanan keperawatan jiwa dimulai dari dibukanya rumah sakit jiwa Bogor,sekarang terdapat 34 Rumah sakit jiwa pemerintah diseluruh Indonesia,salah satunya Medical Record BPRS Dadi Makasasar Provinsi Sulawesi Selatan menunjukkan pasien halusinasi yang dirawat pada tiga tahun terakhir sebagai berikut : pada tahun 2006 jumlah pasien 8710 dengan halusinasi sebanyak 4340 orang (52\%), tahun 2007 jumlah pasien 9245 dengan halusinasi sebanyak 4430 orang (49\%), tahun 2008 (januari-maret) jumlah pasien 2294 dengan halusinasi sebanyak 1162 orang. Daerah provinsi Jawa Barat, pasien yang menjalani rawat jalan dirumah sakit Dr. Marjoeki Mahdi
Bogor Jawa Barat pada empat bulan pertama ditahun 2009 mengalami peningkatan 15\%$20 \%$, peningkatan tersebut terjadi karena peningkatan masyarakat bertambah serta dikarenakan adanya jaminan pengobatan dari pemerintah, tahun 2009, pasien rawat jalan bulan januari 1.297 orang, pebruari 1.301 orang, maret 1.306 orang, dan april 1833 . Tahun 2008, pasien rawat jalan yang berobat kerumah sakit tersebut 19.145 pasien.

Berdasarkan dan survey yang diperoleh dari Rumah sakit Marjoeki Mahdi Bogor, kasus terbanyak yang bulan Januari sampai Desember 2016 adalah dengan diagnosa medis gangguan proses pikir : Halusinasi yaitu $95 \%$. Pada bulan Pebruari 2016 dirumah sakit Dr.Marzoeki Mahdi Bogor masalah keperawatan defisit perawatan merupakan masalah yang berada pada urutan kedua dengan presentasi $80 \%$ dari jumlah klien pada bulan Februari 2016 yaitu 460 jiwa.

Di Rumah Sakit Jiwa Soeharto Heerjdan terdapat ruang perawatan yang terdiri dari ruang perawatan klien akut, ruang perawatan klien intermediet, dan ruang perawatan rehabilitas. Berdasarkan hasil survey data pada tanggal 8 juni 2016 presentase penderita halusinasi dan isolasi sosial pada bulan Januari sampai bulan Juni 2016 adalah sebanyak 97 orang, yang terdiri dari 72 orang $(70 \%)$ merupakan klien dengan diagnosa keperawatan gangguan persepsi: Halusinasi dan 25 orang (30\%) merupakan klien dengan diagnosa keperawatan isolasi sosial. Sedangkan hasil survey penelitian pada tanggal 15 Juni 2016 jumlah pasien halusinasi diruang perawatan rawat inap pada bulan Juni 2016 yaitu 50 orang.

Berdasarkan data dan permasalahan diatas, maka peneliti tertarik untuk mengambil judul hubungan antara tingkat pengetahuan perawat dalam memberikan cara mengontrol dengan perilaku pasien halusinasi pendengaran di RS.Jiwa soeharto Heerdjan Tahun 2016.

\section{Metode}

Metode penelitian adalah usaha untuk menjawab permasalahan, membuat suatu yang masuk akal, memahami peraturan dan memprediksi keadaan dimasa yang akan datang $^{8}$. Pada bagian metode penelitian ini akan diuraikan mengenai desain penelitian, 
populasi penelitian, sampel penelitian, tempat dan waktu penelitian, etika penelitian, prosedur pengumpulan data, alat pengumpulan data, validitas dan pengolahan data.

Jenis penelitian ini merupakan penelitian kuantitatif Desain yang digunakan dalam penelitian ini adalah deskriptif korelasi dengan pendekatan cross sectional yang bertujuan untuk mengetahui hubungan antara variabel. Penelitian ini dilakukan dari bulan JuliNovember 2007 di Rumah Sakit Jiwa Dr. Soeharto Heerdjan Jakarta.

Populasi yang digunakan dalam penelitian ini adalah Pasien yang mengalami gangguan realita atau halusinasi di RS. Jiwa Pusat dr. Soeharto Heerdjan Jakarta 2016 berjumlah 50 orang. Sampel yang terlibat dalam penelitian ini sebanyak 50 orang yaitu pasien yang mengalami gangguan realita atau halusinasi dan menggunakan total sampling.

Pengumpulan data yang digunakan dalam penelitian ini dengan metode kuesioner dan observasi. Metode kuesioner untuk mengukur variabel bebas dan metode observasi untuk mengukur variabel terikat.

Alat yang digunakan untuk mengumpulkan data adalah kuesioner dan lembar observasi. Analisa data yang digunakan yaitu analisa univariat dan bivariat. Analisa univariat adalah analisis untuk mendapatkan gambaran pada masing-masing variabel. Gambaran yang didapat akan dimasukkan ke dalam bentuk table frekuensi dan akan digunakan untuk uji statistik korelasi. Setelah data diolah dengan menggunakan analisa univariat kemudian diolah dengan menggunakan analisa bivariat. ${ }^{9}$

Penelitian ini menggunakan data kategorik sehingga dalam analisa data menggunakan uji chi square. Analisis Bivariat dengan menggunakan Uji Chi Square untuk melihat hubungan peran serta perawat dengan keikutsertaan pasien jiwa terhadap kegiatan mingguan. ${ }^{9}$

Batas kemaknaan yang digunakan adalah $95 \%$ atau $\alpha=0,05$ artinya bila diperoleh $\mathrm{p}<0,05$ berarti secara bermakna ada hubungan antara variabel independen dengan variabel dependen dan bila $\mathrm{p}>$ 0,05 berarti tidak ada hubungan antara variabel independen dengan variabel dependen. ${ }^{10}$

\section{Hasil}

Pengetahuan Pasien Dalam Melakukan Cara Mengontrol Halusinasi.

Tabel 1. Distribusi tingkat pengetahuan

$$
(n=50)
$$

\begin{tabular}{ccc}
\hline $\begin{array}{c}\text { Tingkat } \\
\text { Pengetahuan }\end{array}$ & Jumlah & Persentase (\%) \\
\hline Baik & 29 & 42,0 \\
Kurang Baik & 21 & 58,0 \\
\hline Total & 50 & 100,0 \\
\hline
\end{tabular}

Berdasarkan variabel penelitian didapat data bahwa tingkat pengetahuan pasien dalam melakukan cara mengontrol yang kurang baik sebanyak sebanyak 21 orang dari $50(42,0 \%)$, dan tingkat pengetahuan pasien dalam melakukan cara mengontrol yang baik sebanyak 29 orang dari $50(58,0 \%)$. Hal ini menunjukan masih kurangnya pengetahuan perawat yang optimal dan terjadi setelah orang melakukan penginderaan terhadap suatu objek tertentu. Pengetahuan manusia diperoleh melalui mata dan telinga. Pengetahuan atau kognitif merupakan domain yang sangat penting untuk terbentuknya tindakan seseorang / overt behavior

Tabel 2. Distribusi perilaku pasien halusinasi

$$
(\mathrm{n}=50)
$$

\begin{tabular}{ccc}
\hline Perilaku & Jumlah & Persentase (\%) \\
\hline Destruktif & 29 & 42,0 \\
Konstruktif & 21 & 58,0 \\
\hline Total & 50 & 100,0 \\
\hline
\end{tabular}


Hasil penelitian di rumah sakit Dr. Soeharto Hererdjan Jakarta didapat data bahwa perilaku pasien halusinasi yang destruktif sebanyak 21 orang dari $50(42,0 \%)$, dan perilaku pasien halusinasi pasien yang kontruktif sebanyak 29 dari $50(58,0 \%)$. Hal ini menunjukkan perilaku yang destruktif lebih dominan yang aktif dalam mengikuti ajaran yang telah diberikan oleh perawat terhadap pasien dalam melatih cara mengontrol halusinasi terbukti bahwa perilaku yang didasari oleh pengetahuan akan lebih langgeng dari pada perilaku yang tidak didasari oleh pengetahuan.

Hubungan Antara Tingkat Pengetahuan Pasien Dalam Melakukan Cara Mengontrol Dengan Perilaku Pasien Halusinasi Pendengaran Di Rs Jiwa Soeharto Heerdjan

Hasil analisis menunjukan bahwa tingkat pengetahuan pasien yang kurang baik dalam perilaku pasien halusinasi didapatkan sebanyak $18(85,7 \%)$ dan $3(14,3 \%)$ pasien yang destruktif mengikuti kegiatan, sedangkan tingkat pengetahuan pasien yang baik didapatkan sebanyak $18(62,1 \%)$ pasien yang aktif mengikuti kegiatan dan $11(37,9 \%)$ pasien yang kontruktif. Hasil uji chi-square diperoleh nilai $\mathrm{p}$ value sebesar $0,001<0,05$ sehingga $\mathrm{H} 0$ ditolak, maka disimpulkan bahwa ada hubungan yang signifikan antara tingkat pengetahuan pasien dalam melakukan cara mengontrol dengan perilaku pasien halusinasi di rumah sakit jiwa Dr. Soeharto Heerdjan Jakarta.

\section{Pembahasan}

Pengetahuan adalah segala sesuatu yang diketahui berkenaan dengan hal (mata pelajaran) dan kepandaian. Kategori pengetahuan meliputi kemampuan untuk mengatakan kembali dari ingatan hal-hal khusus dan umum, metode dan prosesnya mengingat suatu pola, susunan, gejala atau peristiwa. Pengetahuan yang tercakup dalam domain kognitif mempunyai tahu, memahami, aplikasi/penerapan, analisis, sintesis, evaluasi. Dalam tersebut dapat diartikan sebagai bahan dasar pengetahuan dalam melakukan cara mengontrol halusinasi kepada pasien. Dari segi biologis, perilaku adalah kegiatan atau aktivitas organisme (makluk hidup) yang bersangkutan. ${ }^{11}$
Oleh sebab itu dari sudut pandang biologis semua makhluk hidup mulai tumbuhtumbuhan, binatang sampai dengan manusia itu berprilaku, karena mereka mempunyai aktivitas masing-masing. ${ }^{12}$

Sehingga yang bermaksud dengan prilaku manusia, pada hakikatnya adalah tindakan atau aktivitas dari manusia itu sendiri yang mempunyai bentangan yang sangat luas antar lain : berbicara, berjalan, menangis, tertawa, kuliah, menulis, membaca dan sebagainya. $^{15}$ Dari uraian ini dapat disimpulkan bahwa yang dimaksud dengan perilaku adalah semua kegiatan atau aktivitas manusia, baik yang dapat diamati langsung, maupun yang tidak dapat diamati oleh pihak luar. $^{13}$

Hasil penelitian ini sejalan dengan Elyani Sembiring penelitian tahun 2006 dengan judul "Tingkat pengetahuan perawat terhadap kemampuan pasien Perilaku Kekerasan dalam Mengendalikan Perilaku Kekerasan di Rumah Sakit Jiwa”. Penelitian deskriptif ini didapatkan hasil 53,3\% pasien perilaku kekerasan kurang dapat mengendalikan amarah dengan baik dan tingkat pengetahuan perawat sebagian besar tinggi (46,3\%)..

Namun kenyataan yang didapatkan peneliti dilapangan, ditemukan pengetahuan pasien yang kurang baik, dimana perawat ruangan masih kurang dalam pengetahuannya, bagaimana cara untuk mengontrol halusinasi kepada pasien dan sehingga pasien tersebut tidak bisa mengontrol halusinasinya dengan baik. Pada saat berjalannya kegiatan cara mengontrol halusinasi para pasien yang kontruktif mengikuti kegiatan tetapi pasien tersebut ada yang masih menyendiri dan berbicara sendiri. Dan fenomena yang terjadi dilapangan pasien tidak terlalu diperhatikan oleh perawat diruangan dalam hal memberikan cara mengontrol halusinasi tetapi malah yang selalu mendampingi pasien tersebut adalah pekerja kebersihan yang ada diruangan tersebut, sehingga pada saat kegiatan memberikan cara mengontrol ditemukan pasien kambuh, yang dimana pasien 
tersebut menyendiri dan asik dengan dunianya sendiri dan terkadang pasien tersebut mengamuk dengan mendegar suara-suara yang mengganggu dia. Sedangkan kegiatan memberikan cara mengontrol ini untuk kesembuhan pasien itu sendiri.

Menurut peneliti, pada penerapan pengetahuan merupakan kemampuan intelektual yang harus dilakukan oleh perawat pada saat melakukan tindakan keperawatan jiwa, untuk itu penerapan strategi pelaksanaan dengan mengontrol halusinasi sangat penting untuk dilakukan pada pasien jiwa, selain dapat menjalin hubungan saling percaya, juga dapat meningkatkan kesembuhan pasien. Mengajarkan cara mengontol halusinasi dalam tindakan keperawatan bayak tidak dilakukan perawat karena banyak faktor salah satunya adanya mahasiswa yang sedang praktek sehingga perawat merasa tidak perlu melakukan pada pasien. Diharapkan bagi rumah sakit dapat mengadakan penyegaran mengenai penerapan strategi pelaksanaan agar perawat termotivasi untuk melakukannya.

Pengetahuan pasien yang kurang baik dapat meyebabkan kurang aktifnya kegiatan. Maka diperlukan pengetahuan pasien yang baik agar kegiatan memberikan cara mengontrol halusinasi tersebut bisa berguna untuk kesembuhan pasien halusinasi. ${ }^{14}$

Hubungan saling percaya antara perawat dan klien merupakan dasar utama dalam melakukan asuhan keperawatan pada klien gangguan jiwa. Hal ini penting karena peran perawat dalam asuhan keperawatan jiwa adalah membantu klien untuk dapat menyelesaikan masalah sesuai dengan kemampuan yang dimilikinya. ${ }^{3}$

\section{Kesimpulan}

Berdasarkan variabel penelitian didapatkan data bahwa tingkat pengetahuan pasien dalam melakukan cara mengontrol yang pada pasien halusinasi yang baik sebanyak 29 orang dari $50(58,0 \%)$ dan perilaku pasien halusinasi yang kurang baik sebanyak 21 orang dari $50(42,0 \%)$.

Berdasarkan variabel penelitian didapatkan data bahwa tingkat pengetahuan pasien dalam melakukan cara mengontrol pasien halusinasi yang destruktif sebanyak 21 orang dari $50(42,0 \%)$ dan perilaku pasien halusinasi yang kontruktif sebanyak 29 orang dari $50(58,0 \%)$.

Berdasarkan analisis bivariat, bahwa responden tingkat pengetahuan pasien yang kurang baik dalam perilaku pasien halusinasi didapatkan sebanyak 18 $(85,7 \%)$ dan $3(14,3 \%)$ pasien yang destruktif mengikuti kegiatan, sedangkan tingkat pengetahuan pasien yang baik didapatkan sebanyak $18(62,1 \%)$ pasien yang aktif mengikuti kegiatan dan 11 (37,9 $\%)$ pasien yang kontruktif. Hasil uji chisquare diperoleh nilai $\mathrm{p}$ value sebesar $0,001<0,05$ sehingga H0 ditolak, maka disimpulkan bahwa ada hubungan yang signifikan antara tingkat pengetahuan pasien dalam melakukan cara mengontrol dengan perilaku pasien halusinasi pendengaran.

\section{Saran}

Hasil penelitian ini dapat memberikan data yang dikaitkan dengan pelayanan keperawatan yang diberikan kepada pasien agar pelayanan keperawatan yang diberikan ditingkatkan untuk mencapai pelayanan yang optimal

Hendaknya pihak Rumah Sakit Jiwa Dr. Soeharto Heerdjan Jakarta dapat membuat SOP (Standar Operasional Prosedur) tingkat mengetahuan pasien dalam mengontrol halusinasi pendengaran.

Guna kepentingan ilmiah maka diharapkan adanya kelanjutan dari penelitian-penelitian selanjutnya, diantaranya: Tentang hubungan tingkat pengetahuan pasien dalam mengontrol halusinasi pendengaran. Peneliti lain dapat menggunakan metode penelitian kualitatif untuk penelitian yang berhubungan dengan peran perawat. 


\section{Daftar Pustaka}

1. Ali, Zaidin. Dasar-Dasar Keperawatan Profesional. Jakarta: Widya Medika, 2001

2. Aziz Alimul Hidayat. Pengantar Konsep Dasar Keperawatan. Jakarta: Salemba Medika, 2004

3. Cholida A. Laporan Penelitian. Hubungan Antara Peran dan Motivasi Perawat Dengan Kegiatan Rehabilitasi Yang Di Ikuti Pasien Jiwa Di Rumah Sakit Jiwa Daerah Provinsi Sumatera Utara, 2009.

4. Sheila, L.V, Buku Ajar Keperawatan Jiwa. Jakarta: EGC, 2008.

5. Simanjutak, J. Konseling Ganguan Jiwa \& Okultisme. Jakarta: PT. Gramedia Pustaka Utama, 2008.

6. Randall, M. Rehabilitation Counseling Basics and Beyound. Austin Texas: PROED Inc, 2005

7. Hawari. Manajemen Stres, Cemas dan Depresi. Jakarta : EGC. 2011

8. Arikunto. Prosedur Penelitian. Edisi Revisi V .Jakarta: Rineke Cipta, 2012.

9. Azis Alimul Hidayat. Metode Penelitian Keperawatan dan Teknik Analisis Data. Jakarta: Salemba Medika, 2008.
10. Notoatmodjo, Soekidjo. Metodologi Penelitian Kesehatan. Edisi Revisi. Rineka Cipta, Jakarta, 2005.

11. Potter, Perry. Fundamental Keperawatan. Jakarta: EGC, 2005.

12. Muhaj, K. Terapi Okupasi dan Rehabilitasi, CV. Intermedia Jakarta, 2009.

13. Maramis, W.F. Catatan Ilmu Kedokteran Jiwa, Edisi 9. Surabaya: Airlangga University Press, 2005.

14. Setyonegoro, Koesumanto. Pedoman Rehabilitasi Pasien Gangguan Mental di Indonesia. Jakarta: Direktorat Kesehatan Jiwa Dep. Kes. RI, 2009.

15. Majnun, D.. Terapi Modalitas Keperawatan Jiwa. Bandung: Binarupa Aksara.2011. 